\title{
Hjertestans hos en ti måneder gammel gutt med ryggmargsskade
}

\author{
En ti måneder gammel gutt med kjent ryggmargsskade ble innlagt med \\ akutt respirasjons- og sirkulasjonssvikt. Kort tid etter innleggelsen fikk \\ han hjertestans.
}

Se kommentar side 1102

\author{
Håvard Trønnes \\ havard.tronnes@isf.uib.no \\ Barneklinikken \\ og \\ Institutt for samfunnsmedisinske fag \\ Universitetet i Bergen \\ Ansgar Berg \\ Barneklinikken \\ og \\ Institutt for klinisk medisin \\ Universitetet i Bergen
}

Da gutten var seks måneder gammel, ble han innlagt $i$ sykehus etter å ha vært involvert $i$ en alvorlig bilulykke. CT av hodet viste små, inoperable blødninger subduralt over høyre hjernehalvdel og subaraknoidalt over venstre pannelapp. MR av ryggsøylen avdekket en skade på ryggmargen fra nivå C6 til $\mathrm{TH} 4$, en rift $i$ dura fra nivå C6 til TH2 og et brudd i ryggvirvel C6 (fig 1). Nakkeskaden ble betraktet som ustabil, men på grunn av barnets alder og størrelse kunne man ikke tilrettelegge nakkekrage. Det ble anbefalt skånsom behandling av nakken, med særlig vekt på å unngå fleksjon og ekstensjon.

Etter hvert kom barnet i gang med rehabilitering. Ryggmargsskaden var inkomplett, og nevrologisk status viste delvis bevart funksjon av armene og nærmest fullsten-

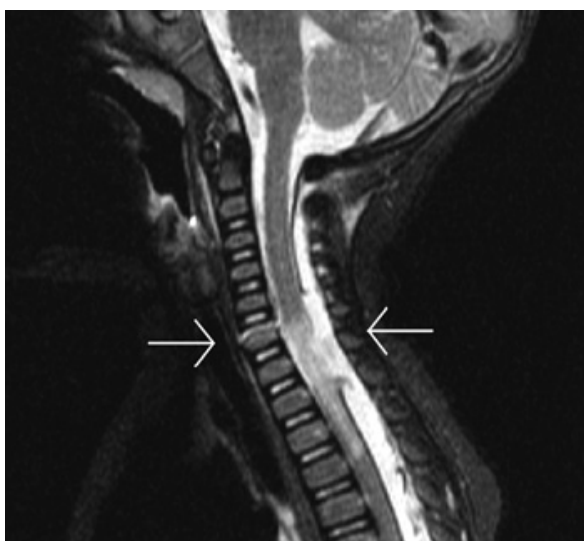

Figur 1 Sagittalsnitt. T2-vektet MR-bilde. Pilene viser skade av ryggmarg fra C6 til Th4, fraktur i C6 og duraruptur dige lammelser i bena. Achilles-og patellarrefleksene var livlige, og det var tegn til begynnende spastisitet. Gjentatte ultralydundersøkelser viste normalt stor urinblære. Ved miksjonsobservasjon så man urinlekkasje og ingen sikker urinstråle, og målinger av resturin viste volumer på mellom $19 \mathrm{ml}$ og $40 \mathrm{ml}$ (normalt blærevolum hos en ettåring er ca. 25-30 ml). Funnene tydet på nevrogen blære, og det ble planlagt oppstart av ren, intermitterende kateterisering (RIK). Fire måneder etter ulykken ble han utskrevet til hjemmet. Av ulike årsaker ble oppstart av kateterisering utsatt til neste planlagte innleggelse.

Nakkeskader hos barn er sjeldent, men kan innebære høy sykelighet og i verste fall død. For de minste barna er trafikkulykker vanligste årsak, mens fall- og sportsulykker er vanligere hos eldre barn (1). Ved høyenergiskade og der det er mistanke om hodeeller nakkeskade må nakken stabiliseres adekvat før klinisk og radiologisk unders $\varnothing$ kelse. Behandlingen av nakkeskader avhenger av barnets alder, nevrologiske status og skadens omfang og nivå.

Hos barn behandles stabile nakkeskader konservativt, og det er lite bevis for at kirurgisk behandling av ustabile nakkeskader begrenser nevrologisk skade (2). Tilpasning av nakkekrage eller annen stabiliserende struktur kan være utfordrende for mindre barn. Ved nevrologiske utfall er det viktig å komme raskt i gang med rehabilitering.

Kort tid etter utskrivningen ble gutten forkjølet, men var igod allmenntilstand. En uke etter hjemkomst ble han utilpass og irritabel. Noen timer senere fikk han plutselig et anfall med cyanose på lepper og ekstremiteter. Anfallet varte i under ett minutt, han var ved bevissthet, og det var ikke kramper eller stivhet i kroppen.

Foreldrene kontaktet lege, som diagnostiserte en dobbeltsidig ørebetennelse. Legen vurderte at gutten var i god allmenntilstand. $P a ̊ ~ l e g e k o n t o r e t$ fikk gutten et liknende anfall, men av lengre varighet og med nedsatt bevissthet. Luftambulansen kom til legekon- toret, og man valgte å sedere og intubere pasienten før transport på grunn av ustabil respirasjon og sirkulasjon.

Hvis et barn har tegn på respirasjons- eller sirkulasjonssvikt, skal det innlegges i sykehus som øyeblikkelig hjelp. Det er viktig å identifisere et slikt barn raskt, slik at man kan planlegge sikker og hurtig transport til sykehus og eventuelt starte behandling.

Respirasjonsvansker hos barn er lett å diagnostisere. Den myke brystkassen gjør at inndragninger $\mathrm{i}$ halsgropen og mellom og under ribbeina blir spesielt godt synlig. Bruk av aksessoriske respirasjonsmuskler og økt respirasjonsfrekvens er tegn på besværet respirasjon. Dype inndragninger, svært rask eller redusert respirasjonsfrekvens, cyanose og oksygenmetning $<92 \%$ er tegn på alvorlig respirasjonsbesvær (3).

Sirkulasjonen kan være vanskelig å bedømme hos barn. Huden er et viktig organ $\mathrm{i}$ bedømmelsen - kalde, klamme ekstremiteter, cyanose og lang kapillær fyllingstid ( $>2$ sek) taler for sirkulasjonsinsuffisiens eller hypotermi. En pålitelig blodtrykksmåling forutsetter at størrelsen på blodtrykksmansjetten er riktig og at barnet er rolig. Målingen må vurderes ut fra alders- og kjønnsjusterte normalområder (4).

En rekke tilstander kan forårsake respirasjons- og sirkulasjonssvikt hos barn. Plutselig respirasjonssvikt kan oppstå ved fremmedlegeme i luftveiene, epileptiske anfall, feberkramper og hjerneblødning. Respirasjonssvikt utløst av luftveisinfeksjoner vil som regel ha et gradvis forløp. Medfødte hjertefeil og hjerterytmeforstyrrelser, som forlenget QT-syndrom eller takyarytmier, kan gi akutt sirkulasjonssvikt. Dehydrering vil forverre sirkulasjonen over tid. Alvorlige infeksjoner som sepsis eller meningitt må alltid vurderes ved presentasjon av livstruende symptomer.

Ved innkomst var barnet intubert og hadde sidelik, surklete respirasjon med frekvens på 28/min og oksygenmetning på $100 \%$. Han hadde en rektaltemperatur på $33,8^{\circ} \mathrm{C}$, var kjølig på ekstremitetene, men hadde et normalt blodtrykk på $80 / 40 \mathrm{~mm} \mathrm{Hg}$ og puls på 95 slag/min. Det ble ikke sett petekkier eller cyanose. Kort tid etter innkomst ble det tatt blodkultur, og det ble gitt intravenøs cefotaksim $(50 \mathrm{mg} / \mathrm{kg}$ ) mot mulig alvorlig infeksjon. EKG var normalt. Innkomstprøvene viste $\mathrm{Hb} 9,2 \mathrm{~g} / 100 \mathrm{ml}$ (9,7-13,3 g/100 ml), leukocytter $8,4 \cdot 10^{9}\left(6,6-16,2 \cdot 10^{9}\right)$, trombo- 
a

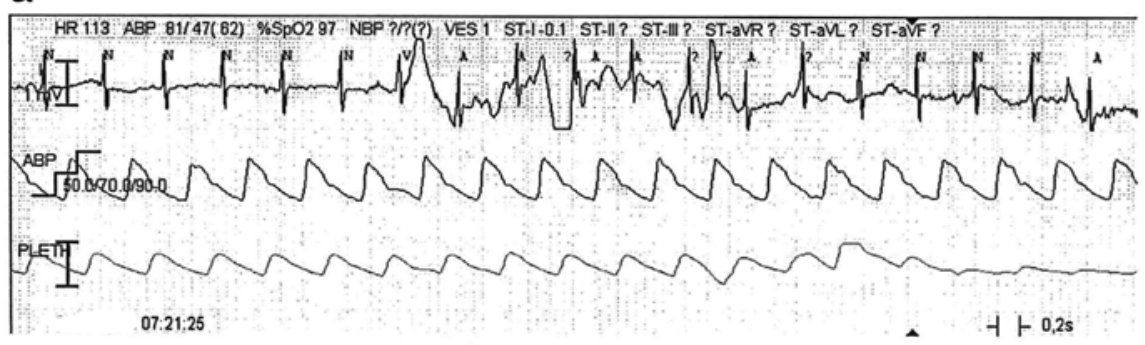

b

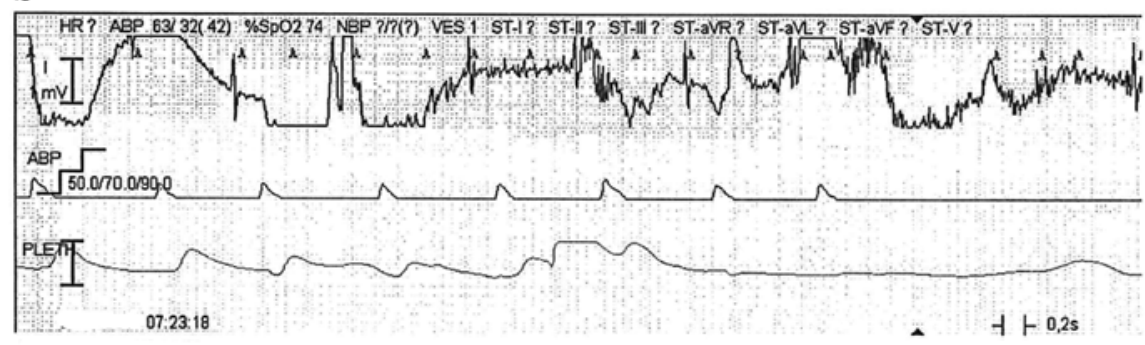

C

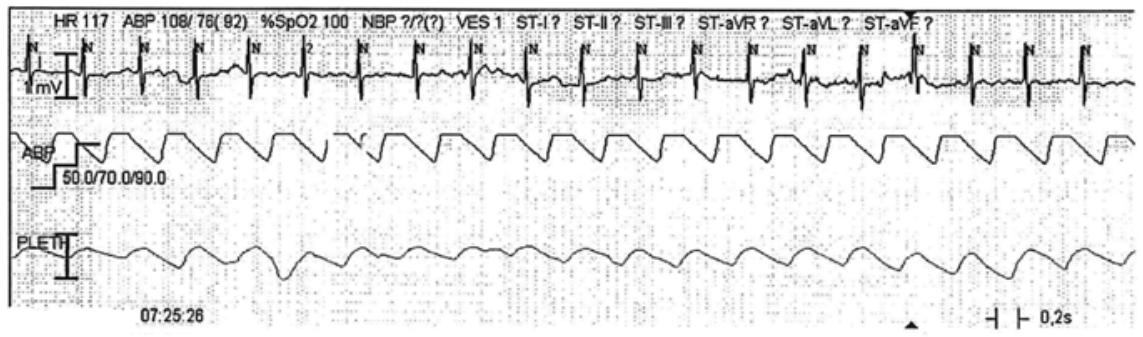

Figur 2 Utskrift av overvåking med EKG (øverst), intraarterielt blodtrykk (midten) og oksygenmetning (nederst) a) før anfall, b) under anfall og c) etter anfall. Bradykardi og deretter asystole under anfallet (b)

cytter $437 \cdot 10^{9}\left(304-619 \cdot 10^{9}\right)$, CRP $26 \mathrm{mg} / \mathrm{l}$ < $5 \mathrm{mg} / \mathrm{l})$ og glukose $7,1 \mathrm{mmol} / \mathrm{l}(4,0-6,0$ $\mathrm{mmol} / \mathrm{ll}$. Kapillær blodgass viste en høy $\mathrm{pO}_{2}$ som følge av høyt oksygentilskudd, men ellers normale verdier. Urinstiks var normal. På bakgrunn av guttens tidligere nakke- og hodeskade ble det bestilt CT av hjernen for å utelukke hjerneblødning.

I røntgenavdelingen fikk barnet akutt bradykardi, fall i oksygenmetning og etter hvert asystole. Det ble startet med avansert hjerte-lunge-redning, og det ble gitt intravenøs adrenalin, albumin og væskestøt gjentatte ganger. Gutten hadde asystole og deretter pulsløs elektrisk aktivitet i 40 minutter før han plutselig fikk bedre farge og pulsgivende rytme. Blodgassundersøkelser under resusciteringen viste normale $\mathrm{pH}$-verdier. CT-unders $\varnothing$ kelsen viste intet patologisk, og ekkokardiografiundersøkelsen var normal. Blodprøvene fra de neste dagene viste ingen leukocytose, en beskjeden stigning av CRP til $37 \mathrm{mg} / \mathrm{l}$ og lett forhøyet prokalsitoninnivå på $2,52 \mu \mathrm{g} / \mathrm{l}$ $<<0,10 \mu \mathrm{g} / \mathrm{l}$ ) som høyeste verdi. Det var ingen vekst av bakterier $i$ urin, blod eller spinalvæske. Spinalvæsken var normal, og PCRundersøkelse for flere virus var negative.

Under respiratorbehandlingen ble det registrert flere kortvarige tilfeller av isolert bradykardi og kombinert bradykardi og blodtrykksfall. Ved ett av disse anfallene så man at gutten i utgangspunktet hadde oksygenmetning på $97 \%$, intraarterielt blodtrykk på 81/47 $\mathrm{mm} \mathrm{Hg}$ og en sinusrytme på $113 \mathrm{slag} / \mathrm{min}$ (fig 2a). Blodtrykket falt så plutselig til 63/32 $\mathrm{mm} \mathrm{Hg}$, etterfulgt av bradykardi på $56 \mathrm{slag} /$ min og oksygenmetning på $74 \%$. Deretter fikk han en asystole på ca. 1,5 sekunder (fig 2b). l et halvt minutt hadde han ikke utslag på blodtrykkskurven, og hjerterytmen falt til 20 slag/min med nærmest opphørt respirasjon. Uten spesifikke tiltak ble både blodtrykk, hjerterytme og oksygenmetning normalisert etter to minutter (fig 2c).

Da pasienten ble innlagt med truet respirasjon og sirkulasjon, var det mistanke om alvorlig infeksjon. Han hadde hatt symptomer på øvre luftveisinfeksjon, etterfulgt av irritabilitet og plutselig forverring av vitale funksjoner. Ved mottak i sykehuset var han hypoterm. Dette kunne skyldes nedkjøling under transport eller en sepsis. Blodprøvene ga ingen klare svar på om det forelå en alvorlig infeksjon, men negative prøvesvar på spinalvæskeundersøkelse, urinstiks, blodkultur og urinkultur svekket hypotesen. Det var ikke holdepunkter for å anta at han hadde hatt kramper, dehydrering eller nedre luftveisinfeksjon. Ekkokardiografi viste ingen medfødte hjertefeil, og EKG viste ingen primær rytmeforstyrrelse eller forlenget QT-tid.
Sett $\mathrm{i}$ lys av ryggmargsskaden ble det konkludert med at han mest sannsynlig hadde autonom dysrefleksi, og han ble utredet med tanke på utløsende årsaker. Det ble ikke funnet sår eller irriterende tilstander nedenfor ryggmargsskaden, og avføringen var normal og regelmessig. Det var kjent at pasienten hadde nevrogen urinblære, og det var ikke startet opp med ren, intermitterende kateterisering. Man mente derfor at den mest sannsynlige årsaken til den autonome dysrefleksien var utvidet urinblære. Dessverre ble ikke urinblæren undersøkt under de aktuelle anfallene. For å motvirke nye, alvorlige anfall fikk barnet implantert permanent pacemaker 12 dager etter innkomst, og foreldrene fikk opplæring i ren, intermitterende kateterisering. Senere cystometriundersøkelser påviste en nevrogen høytrykksblære, og ved en av disse prosedyrene fikk pasienten en moderat bradykardi. Etter ett år har han ikke hatt symptomgivende anfall eller arytmier registrert på pacemakeren.

\section{Diskusjon}

Autonom dysrefleksi er en vanlig og velbeskrevet komplikasjon etter ryggmargsskade. Den opptrer hos $51 \%$ av barn og $48-90 \%$ av voksne med skade i nivåer høyere enn Th6 (5, 6). Autonom dysrefleksi er mindre hyppig ved inkomplette og ikke-traumatiske ryggmargsskader (7). Dysrefleksien kan initieres av en rekke ulike tilstander nedenfor skaden. De aller vanligste tilstandene som utløser autonom dysrefleksi er utvidet urinblære og forstoppelse, som hos barn utgjør $85 \%$ av de utløsende årsaker (5). Tilstander som trykksår, seksuell aktivitet, fødsel, rektaleksplorasjon og stramme klær og sko kan også utløse autonom dysrefleksi $(7,8)$.

Autonom dysrefleksi forårsakes av manglende kommunikasjon mellom det autonome nervesystemet over og under ryggmargsskaden. En bestemt tilstand nedenfor skaden, som for eksempel utvidet urinblære, sender et kraftig sensorisk signal til sentralnervesystemet. De sensoriske signalene kommer ikke forbi ryggmargsskaden og til hjernen, men utløser en sympatisk respons fra ryggmargen nedenfor skaden. Den sympatiske aktiveringen gir generell vasokonstriksjon og blodtrykksstigning. Baroreseptorer $\mathrm{i}$ aortabue, koronar- og halsarterier oppfatter blodtrykksstigningen og formidler signalene til hjernen gjennom hjernenerve 9 (n. glossopharyngeus) og hjernenerve 10 (n. vagus). Hjernen prøver å senke blodtrykket ved å sende hemmende signaler nedover ryggmargen og til hjertet via $n$. vagus. De hemmende signalene som sendes nedover ryggmargen, blokkeres ved skaden. Dette forsterker den parasympatiske responsen med vasodilatasjon ovenfor skaden og bradykardi. Når den parasympatiske responsen ikke er tilstrekkelig for å senke blodtrykket, vil den autonome dysrefleksien bli opprettholdt inntil den utløsende årsaken opphører $(6,7)$ (fig 3). 


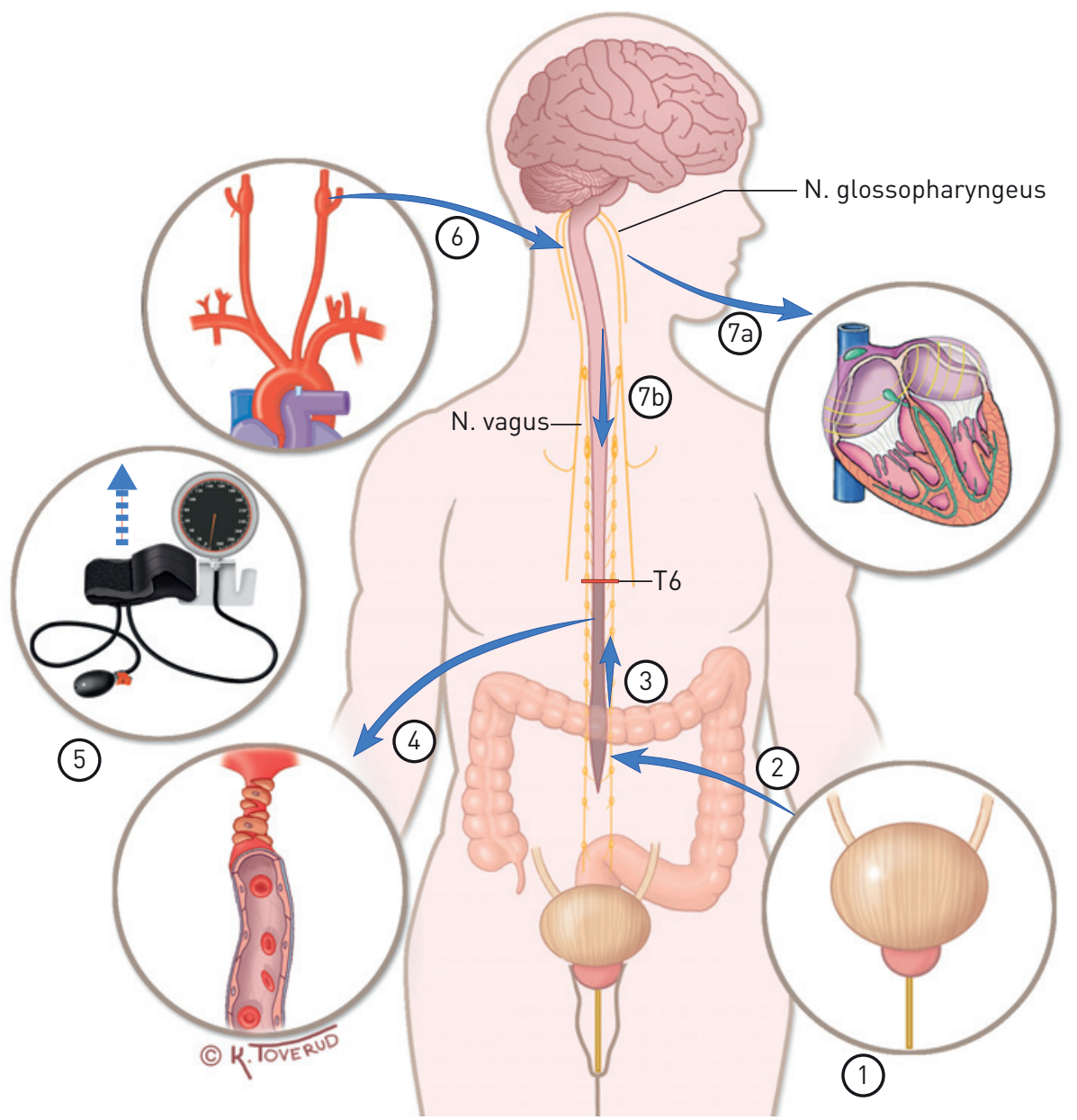

(1) Utvidelse av urinblære eller annen autonom stimulus

(2) Sensoriske signaler sendes til sentralnervesystemet

Signalene kommer ikke forbi ryggmargsskaden

(4) Sympatisk respons utløses fra ryggmargen nedenfor skaden

(5) Responsen gir generell vasokonstriksjon og blodtrykksstigning

6) Blodtrykksstigningen aktiverer baroreseptorer, som formidler dette til hjernen

7a Hjernen prøver å senke blodtrykket ved å sende hemmende signaler til hjertet

(7b) og nedover ryggmargen. Signalene i ryggmargen blokkeres ved skaden. Dette forsterker parasympatisk respons med vasodilatasjon ovenfor skaden og bradykardi

Figur 3 Skjematisk fremstilling av autonom dysrefleksi. Figuren er basert på en illustrasjon fra Canadian Medical Journal, som har gitt tillatelse til publisering

Det er vanskelig å diagnostisere autonom dysrefleksi, med mindre man kjenner til tilstanden fra før. Typiske symptomer er ansiktsrødme, hodepine, svetting og piloereksjon (gåsehud). Barn under fem år forteller sjelden om hodepine, og ingen får piloereksjon $(5,7)$. Diagnosen stilles ved at man registrerer en systolisk blodtrykksstigning på mer enn $15 \mathrm{~mm} \mathrm{Hg}$ hos barn og mer enn $20 \mathrm{~mm} \mathrm{Hg}$ hos voksne, ledsaget av en eller flere typiske symptomer og tegn $(5,8)$. En blodtrykksstigning må relateres til pasientens habituelle blodtrykk. Selv om bradykardi er typisk ved autonom dysrefleksi, kan variasjoner i responsen på den autonome påvirkningen gi både normal hjertefrekvens og takykardi (5, $7,8)$. Alvorlighetsgraden av autonom dysrefleksi kan variere fra asymptomatisk, forbigående hypertensjon til livstruende tilstander som hjerneblødning og hjertestans (9).

Den akutte behandlingen av autonom dysrefleksi retter seg mot å fjerne utløsende årsak og få blodtrykket ned. Pasienten skal bringes i sittende posisjon for å senke blodtrykket, og potensielle triggere som stramme klær, belte og sko fjernes. Deretter må man undersøke de vanligste utløsende årsakene, som utvidet urinblære og forstoppelse, og eventuelt sette inn tiltak mot dette. Ved en hypertensiv krise må man iverksette hurtigvirkende blodtrykkssenkende behandling, og nifedipin eller nitrater brukes mest på voksne og barn $(8,10,11)$. Ved symptomgivende hypotensjon, bradykardi eller asystole må man følge vanlige retningslinjer for resuscitering, men samtidig prøve å identifisere og eliminere utløsende årsak.

Vår pasient hadde en uvanlig klinisk manifestasjon av autonom dysfunksjon, både med tanke på alvorlighetsgrad og presentasjon. Vi har ikke lyktes i å finne kasuistikker om livstruende anfall av autonom dysrefleksi hos barn. Gutten oppfylte ikke kriteriet med blodtrykksstigning under anfall, men vi har ikke opplysninger om hans habituelle blodtrykk, og pasienter med ryggmargsskade kan ha et vedvarende lavt blodtrykk $(11,12)$. Det er derfor mulig at han kan ha hatt blodtrykksstigning. I en retrospektiv studie av autonom dysrefleksi hos barn hadde to barn under fem år ikkesignifikant blodtrykksstigning under anfall (5). De hadde også uspesifikke symptomer som slapphet og irritabilitet.

Pasienten vår fikk hypotensjon under anfall, mens man ville ha forventet hypertensjon. Dette kan forklares ved en sterk parasympatisk stimulering med vasodilatasjon og vagal påvirkning av hjertet med negativ inotropi og senkning av hjerterytmen. Alvorlig hypotensjon og bradykardi etter ryggmargsskade (nevrogent sjokk) er velbeskrevet hos voksne, men forekommer i den akutte fasen etter skaden (6). Det er imidlertid flere kasuistikker som beskriver voksne pasienter med behov for permanent pacemaker på grunn av residiverende anfall av hypotensjon og bradykardi (12).

Siden vår pasient ikke hadde hypertensjon, ble behandlingen rettet mot utløsende årsak og anfallsbegrensende tiltak. Den antatt utløsende årsak var en utvidet urinblære, og denne ble behandlet med regelmessig kateterisering. Behandlingen med pacemaker vil ikke ha effekt på vasodilatasjon og hypotensjon, men vil hindre en samtidig bradykardi, som vil forverre situasjonen. Pasienten har ikke hatt symptomgivende anfall eller arytmier etter at behandlingen med pacemaker og ren, intermitterende kateterisering ble startet, noe som understøtter diagnosen autonom dysrefleksi.

Tilstanden var vanskelig å diagnostisere av flere grunner. Pasientens sykehistorie og kliniske tilstand ledet tankene mot infeksjon som grunnsykdom. Man var ikke oppmerksom på risikoen for autonom dysrefleksi, og foreldrene var heller ikke informert om denne tilstanden etter guttens første sykehusopphold. På grunn av alderen kunne han ikke redegjøre for sine symptomer, og han fikk alvorlig autonom dysrefleksi uten andre ledsagende tegn. 


\section{Konklusjon}

Autonom dysrefleksi er en medisinsk akuttsituasjon med potensielt fatale konsekvenser. Vårt hovedbudskap er at alt helsepersonell som møter ryggmargsskadede må ha kjennskap til autonom dysrefleksi. På Internett finnes det fritt tilgjengelig evidensbaserte retningslinjer for diagnostikk og behandling (8). Pasienter som får ryggmargsskade og deres pårørende må informeres grundig om autonom dysrefleksi. Ved at pasienter, pårørende og helsepersonell har gode kunnskaper om tilstanden, kan man forebygge og behandle den på en effektiv måte.

Pasientens foreldre har gitt samtykke til at artikkelen blir publisert.

\section{Håvard Trønnes (f. 1974)}

er spesialist i barnesykdommer. Han er konstituert overlege ved Barneklinikken ved Haukeland universitetssykehus og ph.d.-stipendiat ved Institutt for samfunnsmedisin, Universitetet i Bergen.

Oppgitte interessekonflikter: Forfatteren har mottatt reisestøtte fra GSK.

\section{Ansgar Berg (f. 1967)}

er seksjonsoverlege ved Barneklinikken ved Haukeland universitetssykehus og professor II ved Institutt for klinisk medisin, Universitetet i Bergen.

Ingen oppgitte interessekonflikter.

Litteratur

1. Cirak B, Ziegfeld S, Knight VM et al. Spinal injuries in children. J Pediatr Surg 2004; 39: 607-12.

2. Parent S, Dimar J, Dekutoski M et al. Unique features of pediatric spinal cord injury. Spine 2010; 35 (suppl): S202-8.

3. Pettersen M, Halvorsen T, Carlsen KH. Akutt bronkiolitt. I: Akuttveileder. www.legeforeningen.no/id/ 122369.0 (5.8.2011).

4. Hirth A, Brackman D, Greve G. Blodtrykksmåling hos barn. I: Generell veileder. www.legeforeningen.no/id/110357.0 (5.8.2011).

5. Hickey KJ, Vogel LC, Willis KM et al. Prevalence and etiology of autonomic dysreflexia in children with spinal cord injuries. J Spinal Cord Med 2004; 27 (suppl 1): S54-60.

6. Grigorean VT, Sandu AM, Popescu M et al. Cardiac dysfunctions following spinal cord injury. J Med Life 2009: 2: 133-45.

7. Bycroft J, Shergill IS, Chung EA et al. Autonomic dysreflexia: a medical emergency. Postgrad Med J 2005; 81: 232-5.

8. National guideline clearinghouse. Acute management of autonomic dysreflexia: individuals with spinal cord injury presenting to health-care facilities. http://guideline.gov/content.aspx?id=2964 (5.8.2011).

9. Krassioukov A, Warburton DE, Teasell R et al. A systematic review of the management of autonomic dysreflexia after spinal cord injury. Arch Phys Med Rehabil 2009; 90: 682-95.

10. Furlan JC, Fehlings MG. Cardiovascular complications after acute spinal cord injury: pathophysiology, diagnosis, and management. Neurosurg Focus 2008; 25: E13

11. McGinnis KB, Vogel LC, McDonald CM et al. Recognition and management of autonomic dysreflexia in pediatric spinal cord injury. J Spinal Cord Med 2004; 27 (suppl 1): S61-74.

12. Franga DL, Hawkins ML, Medeiros RS et al. Recurrent asystole resulting from high cervical spinal cord injuries. Am Surg 2006; 72: 525-9.

Mottatt 9.4. 2011, første revisjon innsendt 22.8. 2011, godkjent 15.9. 2011. Medisinsk redaktør Are Brean.

\section{Kommentar}

\section{Bradyarytmier tidlig etter ryggmargsskade}

Spinale tverrsnittslesjoner hos barn er sjeldent forekommende (1). Sammenliknet med tilsvarende skader hos voksne har barn relativt flere høye cervikale skader og relativt flere med iatrogene årsaker. I Norge har barneavdelingene selv hovedansvaret for både behandling og rehabilitering av barn med spinale tverrsnittslesjoner, mens voksne med slike lesjoner rehabiliteres i henholdsvis Sunnaas sykehus, Haukeland universitetssykehus og St. Olavs hospital.

Den aktuelle kasuistikken forteller om en seks måneder gammel gutt som blir påført en alvorlig høy spinal tverrsnittslesjon i en trafikkulykke. Fire måneder senere, en uke etter utskrivning til hjemmet, blir han reinnlagt med hjertestans. Man konkluderer med at årsaken til hjertestansen er autonom dysrefleksi, som behandles med hjertepacemaker.

Klinisk nivådiagnostikk og vurdering $\mathrm{i}$ henhold til konsensusbaserte retningslinjer fra American Spinal Injury Association (ASIA) og International Spinal Cord Society (ISCoS) er vanskelig å gjennomføre hos små barn. Autonom dysrefleksi er en velkjent komplikasjon, som også tidligere er beskrevet i Tidsskriftet (2).

Det finnes imidlertid andre årsaker enn autonom dysrefleksi til bradykardi og hjertestans i forløpet etter cervikale ryggmargsskader (3). Den hyppigste og mest fryktede årsaken er bradykardi og hjertestans som følge av luftveisproblemer og manipulering med luftveiene (4). Vi vet at pasienter med cervikale ryggmargsskader, uansett skadenivå, har problemer med hosterefleksen og derfor er utsatte for slimopphopning. Både slimopphopning og suging kan utløse bradykardi og hjertestans. Årsaken til bradykardien og ev. asystolien antas å være en vagovagal refleks der både afferente og efferente signaler forløper i n. vagus (4). Bortfall av sympatisk aktivitet og hypoksi forsterker denne refleksen. Den umiddelbare behandling er derfor surstofftilførsel og atropin, som alltid skal være lett tilgjengelig ved luftveisdrenering av pasienter med cervikale ryggmargsskader.

I det aktuelle tilfellet, hvor det er beskrevet at pasienten i forbindelse med første hjertestansepisode hadde luftveisinfeksjon, er det min oppfatning at luftveisproblemene og håndteringen av disse, ikke autonom dysrefleksi, var årsaken til hjertestansen. Pacemakerbehandling kan ha vært indisert uansett.

Det anbefales å ta kontakt med norske spinalenheter og med for eksempel barnerehabiliteringsavdelingen ved Shriners Hospital i Chicago (www.shrinershospitalsforchildren.org/Chicago/SpinalCord.aspx) når slike tilfeller inntreffer.

\section{Nils Hjeltnes}

nils.hjeltnes@sunnaas.no

Sunnaas sykehus

Nils Hjeltnes (f. 1943) er spesialist i fysikalsk medisin og rehabilitering og dr.med. fra Karolinska Institutet. Han er fagsjef leger og seniorrådgiver ved Sunnaas sykehus. Hans spesialfelt er rehabilitering av ryggmargsskadede. Han har vært president i NoSCoS (NordicSpinalCordSociety).

Ingen oppgitte interessekonflikter.

\section{Litteratur}

1. Hagen EM, Eide GE, Elgen I. Traumatic spinal cord injury among children and adolescents; a cohort study in western Norway. Spinal Cord 2011; 49: $981-5$

2. Hjeltnes N, Gjone R. Autonom dysrefleksi ved medullære tverrsnittlesjoner. Tidsskr Nor Lægeforen 1983; 103: 1933-6.

3. Franga DL, Hawkins ML, Medeiros RS et al. Recurrent asystole resulting from high cervical spinal cord injuries. Am Surg 2006; 72: 525-9.

4. Mathias CJ. Bradycardia and cardiac arrest during tracheal suction-mechanisms in tetraplegic patients. Eur J Intensive Care Med 1976: 2: 147-56. 